\title{
Reservoir quality of Cenozoic carbonate buildups and coral reef terraces
}

\section{Moyra E.J. Wilson}

${ }^{1}$ The Institute for Geoscience Research, Department of Applied Geology, Curtin University, GPO Box U1987, Perth, Western Australia 6845, m.wilson@curtin.edu.au

Almost half of SE Asia's considerable hydrocarbon reserves are contained in carbonates. The majority of these reservoirs are Miocene buildups up to tens of kilometres across. However, with the exception of a few fields, there is little detailed data on how local depositional and diagenetic conditions influence the considerable heterogeneities in reservoir quality often encountered. This study focuses on factors influencing the facies, diagenetic and reservoir variability of comparable Modern, Quaternary and Neogene reef associated deposits from the Tukang Besi Archipelago, Central Indonesia.

The Archipelago includes large atolls, a number of smaller buildups and 4 main islands each with modern rimmed shelves or fringing reefs. On the islands, over ten late Neogene and Quaternary coral reef terraces have been uplifted to maximum heights of $\sim 300 \mathrm{~m}$. Analysis of the modern deposits allows initial reservoir potential to be assessed and related to local environmental conditions. The influence of diagenesis on final reservoir quality is evaluated for the depositional facies exposed in the uplifted terraces. The overall spatial distribution of effective porosity across the area is strongly dependent on local energy conditions, water depth, carbonate producers, size of atolls or islands, climate and local meteoric diagenetic processes. This evaluation of spatial variability in carbonate reservoir characteristics provides much needed analogue data as the hydrocarbon industry focuses on improving recovery from existing fields and exploring for new reserves.

\section{Introduction}

Almost half the world's oil production (Dickey, 1986), and a similar percentage of Indonesia's hydrocarbon production (Park, 1995) is from carbonate reservoirs. The majority of SE Asia's reserves are in carbonate buildups of Neogene age with major new discoveries continuing to be found in these deposits (e.g. the Kujung Formation in the East Java Sea). Greenlee and Lehmann (1993) showed that $>45 \%$ of hydrocarbon 
reserves contained in Phanerozoic productive carbonate buildups were in Miocene systems (containing $>16.5$ BBOE), with most of these in SE Asia. Despite the clear economic importance of Neogene buildups as reservoir targets, there are very few studies of analogous modern or Neogene outcrops in SE Asia. Detailed modern studies are restricted to those of the Pulau Seribu system, offshore Jakarta (Scrutton, 1978; Park et al., 1992 Jordon, 1998). These high-energy, small-scale buildups developed on the shallow shelf bordering the island of Java and do not encompass the variety of carbonate depositional systems seen throughout the region. Sedimentological and diagenetic analysis of the Tacipi Formation of South Sulawesi is one of the very few detailed studies of outcropping Negoene carbonate buildups (Grainge \& Davies, 1983; Mayall \& Cox, 1988, Ascaria et al., 1997). There is considerable need for new evaluations of modern and Neogene carbonate systems to provide analogue data to aid in reservoir prediction of subsurface buildups.

This manuscript reports on preliminary results of an ongoing project to evaluate influences on marine environmental change, facies distribution and potential reservoir development of modern and late Cenozoic carbonate buildups in the Tukang Besi Archipelago (or Wakatobi region), offshore SE Sulawesi. The Wakatobi area is ideal to study buildup development because it includes a range of diverse carbonate depositional systems associated with isolated, small-scale buildups, fringing/barrier reefs around islands, large and small-scale atolls. Over 10 different uplifted coral reef terraces are preserved on individual islands in the Wakatobi chain and onshore Buton. These late Cenozoic deposits allow assessment of how environmental change and diagenesis impact on reservoir quality of Cenozoic carbonate buildups. The morphology and development of the archipelago was much debated in the early part of last century (Escher, 1920; Hetzel, 1930; Kuenen, 1933a; b; Umbgrove, 1947; van Bemmelen, 1949; Tomascik et al., 1997; Milsom et al., 1999). However, until now there has been no detailed work on the shallow-marine or onshore carbonate deposits. Over 6 months of field data collection has been completed for this project and laboratory analysis is underway. Publications of final results are planned for international publication when analysis is complete.

The overall objectives of the study are: 
- To map out, and evaluate controls on, modern carbonate sediment distribution patterns

- To compare the sedimentary characteristics and reservoir quality of limestones exposed onshore with analogous modern reefal-associated sediments

- To reconstruct how marine carbonate-producing environments have changed in the region over the last 5 million years, and to evaluate factors influencing these changes.

- To evaluate how depositional setting and diagenesis have influenced reservoir quality of carbonate buildups in the Wakatobi region.

- To provide analogue data to aid in reservoir characterisation of comparable Neogene subsurface buildups in SE Asia.

\section{Methodology}

A range of field and laboratory techniques were utilised to study the modern reefs and their associated deposits of the Wakatobi region, together with their uplifted Pliocene/Quaternary equivalents which crop out as exposures on the islands (Figure 1). Fieldwork, totalling $>6$ months has now been completed on a range of modern environments and onshore all islands in the Wakatobi and south Buton region. Laboratory analysis and analysis of results is ongoing.

The modern settings were surveyed and deposits sampled along underwater transects, generally perpendicular to the trend of the reef crest (i.e. from deep forereef areas, passing across the shallow reef crest to inner reef or land areas). Study was through diving and snorkelling and recording local environmental conditions where changes in sediment-types occur. For regions deeper than 20-30 m additional samples were obtained using a sediment grab. In total, $>40$ modern transects were studied, with over 300 samples of modern reef-associated sediments collected. The components, their alteration, grain size distribution and primary porosity of individual samples are now being studied through microscopy of sediment samples, petrography of grain mounts and laser granulometry.

Geological surveying and carbonate sample collection has been completed onshore all islands in the Wakatobi chain (Wangi Wangi, Hoga, Kaledupa, Lintea Utara Tomea, Lintea Selatan, Binongko and Runduma Islands) as well as on South Buton. 
Field sedimentology, facies mapping, geomorphological and in situ macropalaeontological observations have been recorded across thirtyfive transects starting at the shoreline up to high points on the islands. Further petrographic and geochemical analysis of the $400+$ carbonate samples collected is underway to evaluate past environmental change, diagenesis and potential reservoir development. Laboratory analysis currently underway includes petrography of stained thin sections, stable isotope geochemistry $\left(\delta^{18} \mathrm{O}\right.$ and $\left.\delta^{13} \mathrm{C}\right)$, isotopic dating, scanning electron and cathodoluminescence microscopy. PETREL modelling to evaluate reservoir quality distribution is being undertaken in collaboration with Nigel Deeks from Schlumberger.

\section{Modern carbonates}

The Wakatobi Archipelago provides an excellent opportunity to characterise and evaluate controls on modern coral reef associated sediments in SE Asia. Tomascik et al., (1997) described the archipelago as 'a classic example of atoll and barrier reef formation', although the systems are more varied than this. The wide diversity of depositional systems include large-scale atolls (Karang Kaledupa, Karang Kapota), smallscale atolls less than $10 \mathrm{~km}$ across (Karang Koka, Karang Koromaha, Tokabau), small scale buildups lacking a significant interior lagoon (Ndaa, Cowocowo, Kentiolo, and Moro Maha) and barrier/fringing reefs around islands (Wangi wangi, Kaledupa, Tomea, Binongko, Runduma, Kapota, Kampanauwe, Hoga, Lintea Utara and Selatan). It is this variability that renders the area as exceptional to characterise modern carbonate deposits in SE Asia, yet to date no detailed studies of the sediments have been undertaken.

The archipelago is located over $20 \mathrm{~km}$ to the southeast of Buton in SE Sulawesi. It consists of three, roughly linear rows of atolls, islands and buildups trending northwestsoutheast that rise from a broader platform (700-1000m water depth) of possible continental origin (Smith and Silver, 1991; Koswara and Sukarna, 1994; Milsom et al., 1999). All modern depositional systems in the archipelago are isolated from siliciclastic input as they each rise from water depths of over $700 \mathrm{~m}$ in the Western Banda Sea. The tidal range is $\sim 2 \mathrm{~m}$, and currents are often very strong, particularly between islands/atolls. Wave energy can be high and is strongly seasonal being dependent on the monsoon winds. Very strong south-easterlies blow between June to August, whereas westerlies of lesser strength affect the area between December to March. Sampling of north eastern 
sides of islands and many of the high energy outlying sites (Binongko, Runduma, Ndaa, Moro maha etc) was only possible during the short window of usually calmer weather between September and November.

It is inferred from preliminary analysis of the modern deposits that there are distinctive variations in the carbonate sediments from different local environments associated with the reefs. Characterisation of environments was through analysis of macrobiota, their morphologies and sediment characteristics (components, grain size and alteration). Preliminary results show that beach, inner and outer reef flat, reef crest, reef slope, forereef, moderate energy and high energy lagoon deposits can all be distinguished. It is also possible to evaluate relative water depths and energy of formation of the deposits. There appears to be distinct variations between deposit and terrace development on windward and leeward sides of islands, with windward terraces generally being narrower and formed under higher energies than their leeward counterparts. Figure 2 shows an example of deposit characterisation typical of a leeside fringing reef.

\section{Pliocene/Quaternary carbonates}

The Wakatobi islands preserve a unique record of ancient uplifted coral reefs that formed within the last 5 million years. These ancient reefs are exposed as a series of stepped terrace levels that have been uplifted to maximum heights of $300 \mathrm{~m}$. The deposits of each terrace formed in a variety of shallow marine environments associated with coral reefs that built towards sea level. As the shallow water deposits became emergent due to uplift forming a 'terrace', a new active fringing reef system developed around the emerging island. On subsequent uplift this 'new' reef becomes a lower, and younger emergent terrace level. Thus on each of the islands the older terrace levels are exposed at greater elevations with younger terrace development sequentially closer to current sea level. The shallow water reef deposits (limestone terraces) overlie deeper water marls of Late Miocene and Early Pliocene age (the Ambewa Formation, Koswara \& Sukarna, 1994). Rare exposures of older basement thought to be of continental origin have been reported on Runduma (Koswara \& Sukarna, 1994). Despite an extensive search for these older rocks on Runduma no in situ exposures were located. However, blocks of silica-rich and ferromagnesium-rich igneous rocks were found. The latter, if originating on 
Runduma would throw into doubt the hypothesis of purely continental crust underlying the region (cf. Cornée et al., 2002).

Through analysis of fossil types, their morphologies (Crabbe et al., 2006) and deposit characteristics the environments of formation of the uplifted reef terraces are being determined. GPS locations and heights were recorded for each location together with geomorphic markers, deposit sediment texture, grain size and components. Data on the deposits of the modern reefs is being used as a modern analogue to aid this interpretation. Preliminary results indicate that a similar range of environments can be characterised in the terraces as are seen in the modern environments today. By analogy with the modern sediments it is also possible to evaluate past environmental change in the region and to evaluate influencing factors. Figure 3 shows an example of data collected and interpretations made for just one of the transects from across the leeside of the island of Tomea.

A complex series of oceanographic, climatic, tectonic and eustatic factors influence deposit types and terrace development. The findings of this research have shown that a series of over 10 different stepped coral reef terraces have developed within the last 5 million years. Since the highest terrace level, at over $300 \mathrm{~m}$, is significantly greater than any known eustatic sea level fall there has to be a strong element of tectonic uplift in the region, related to regional tectonics. Tracking the height of individual terrace levels has to date not revealed any significant systematic height variations which might have been suggestive of tectonic tilting or folding in the region. Further analysis of the data set together with high resolution dating is required to determine whether differential tectonic uplift has affected the different islands, and the relative roles of tectonics, eustasy and oceanography.

\section{Reservoir quality}

The reservoir potential of the terraces is being evaluated through combining the original deposit characteristics together with their diagenetic overprint. Further petrographic, scanning electron microscopy (SEM), cathodoluminescent (CL) and geochemical studies are helping reveal how diagenetic environments and paragenetic sequences have influenced porosity and permeability. Preliminary results are that marine cements are concentrated in windward reef crest environments, whereas micritization of 
grains was particularly prevalent in shallow leeside deposits. Meteoric influences markedly affected shallow water deposits, although both leaching and cementation resulted. In general reservoir quality is best developed in high energy shoal deposits, in windward reef flat or slope deposits, and in leeside crest and shallow slope deposits. These findings are comparable with studies of other high energy margins (Wilson and Evans, 2002) or buildups, such as those of the subsurface productive Neogene buildups offshore the Philippines (Nido Limestone; Grötsch and Mercadier, 1999)

\section{Summary}

When complete this study will provide a unique insight into the character and distribution of modern and late Cenozoic deposits from a wide range of depositional environments associated with isolated carbonate platforms and buildups in SE Asia. By focusing on factors influencing facies, diagenetic and reservoir variability this study provides constraints on marine environmental change together with much needed reservoir analogues for prospective Neogene subsurface buildups.

Preliminary results are that reservoir quality is best developed in high energy shoal deposits, in windward reef flat or slope deposits and in leeside crest and shallow slope deposits. This evaluation of spatiotemporal variability in reservoir potential of carbonate buildups provides much needed analogue data as the hydrocarbon industry focuses on improving recovery from existing fields and exploring for new reserves.

\section{Acknowledgements}

Research has been supported by, and run in collaboration with, Operation Wallacea and the SE Asia Research Group (London University). In addition to members of these organisations Moyra Wilson acknowledges the input of a number of Honours/Masters students and colleagues (Nigel Deeks, Gareth Fenney, Colin Guyton, Emil Naylor-Morell, Maeve O’Shea, Katie Roberts and Paul Whipp) who have worked together with her on this project.

\section{References}

Ascaria, N.A., Harbury, N.A., Wilson, M.E.J., 1997. Hydrocarbon Potential and development of Miocene knoll-reefs, South Sulawesi. In: Howes, J.V.C., Noble, R.A. (Eds.). Proceedings of an 
International Conference on Petroleum Systems of SE Asia \& Australasia, Indonesian Petroleum Association, 569-584.

Cornée, J.-J., Villeneuve, M., Ferrandini, M., Hinschberger, F., Malod, J.A., Matsumaru, K., RibaudLaurenti, A. and Rehault, J.-P., 2002. Oligocene reefal deposits in the Pisang Ridge and the origin of the Lucipara Block (Banda Sea, eastern Indonesia). Geo-Marine Letters 22, 66-74.

Crabbe, M.J.C, Wilson, M.E.J. \& Smith, D.J., 2006. Quaternary corals from reefs in the Wakatobi Marine National Park, SE Sulawesi, Indonesia, show similar growth rates to modern corals from the same area. Journal of Quaternary Science, 21, 803-809.

Dickey, P.A. 1985. Petroleum development geology. Penwell Publishing Company. 530 p.

Escher, M.G. 1920. Atollen in den Nederlandsch-Oost-Indischen Archipel. Med Encyclopedisch Bureau, Weltevreden XXII.

Grainge, A.M., Davies, K.G., 1983. Reef exploration in the east Sengkang basin, Sulawesi, Indonesia. Indonesian Petroleum Association, Proceedings 12th Annual Convention, 207-227.

Greenlee, S.M. and Lehmann, P.J., 1993, Stratigraphic framework of productive carbonate buildups, in Loucks, R.G., and Sarg, J.F., eds., Carbonate sequence stratigraphy, recent developments and applications. American Association of Petroleum Geologists, Memoir 57, p. 267-290.

Grötsch, J. and Mercadier, C., 1999. Integrated 3-D reservoir modeling based on 3-D seismic: The Tertiary Malampaya and Camago buildups, offshore Palawan, Philippines. American Association of Petroleum Geologists Bulletin 83, 1703-1728.

Hetzel, W.H. 1930. Over de Geologie Der Toekang-Besi Eilanden. De Mijningenieur, 11, 51-53.

Jordan, C.J., 1998. The sedimentation of Kepuluan Seribu: A modern patch reef complex in the West Java Sea, Indonesia. Indonesian Petroleum Association Field Guide, 81 p.

Koswara, A. and Sukarna, D. 1994. Geology of the Tukangbesi Sheet, Sulawesi. Geological Research and Development Centre, Bandung, Indonesia, 14 p \& map.

Kuenen, Ph.H. 1933a. The Geology of Coral reefs. The Snellius Expedition in the eastern part of the Netherlands East Indies 1929-1930. Proc. Kon. Akad. V. Wetensch., Amsterdam 36, 125 p.

Kuenen, Ph.H. 1933b. The formation of the atolls in the Toekang-Besi-group by subsidence. Proc. Kon. Akad. V. Wetensch., Amsterdam 36, 331-336.

Mayall, M.J., Cox, M., 1988. Deposition and diagenesis of Miocene limestones, Sengkang Basin, Sulawesi, Indonesia. Sedimentary Geology 59, 77-92.

Milsom, J., Ali, J., and Sudarwono, 1999. Structure and collision history of the Buton continental fragment, Eastern Indonesia. AAPG Bulletin, 83, 1666-1689.

Park, R.K., Matter, A., and Tonkin, P.C., 1995, Porosity evolution in the Batu Raja Carbonates of the Sunda Basin - Windows of opportunity: Indonesian Petroleum Association, Proceedings 24th Annual Convention, p. 63-184.

Park, R.K., Siemers, C.T., Brown, A.A., 1992. Holocene Carbonate Sedimentation, Pulau Seribu, Java Sea, - The Third Dimension. In: Siemers, C.T., Longman, M.W., Park, R.K., Kaldi, J.G. (Eds.). Carbonate Rocks and Reservoirs of Indonesia, a Core Workshop. Indonesian Petroleum Association, 2-1 - 2-15.

Scrutton, M., 1977/78. Modern Reefs in the West Java Sea. SEAPEX Proceedings IV, 22-40.

Smith, R.B. \& Silver, E.A. 1991. Geology of a Miocene collision complex, Buton, eastern Indonesia. Geological Society of America Bulletin, 103, 660-678.

Tomascik, T., Mah, A.J., Nontji, A., Moosa, M.K., 1997. The Ecology of the Indonesian Seas. Oxford University Press, $1388 \mathrm{p}$.

Umbgrove, J. H. F., 1947. Coral reefs of the East Indies. Bulletin of the Geographic Society of America $58,729-778$.

van Bemmelen, R.W., 1949. The Geology of Indonesia. Vol. 1a. Govt. Printing Office, The Hague (2nd edition, 1970), $732 \mathrm{p}$.

Wilson, M.E.J. \& Evans, M.J. 2002. Sedimentology and diagenesis of Tertiary carbonates on the Mangkalihat Peninsula, Borneo: implications for subsurface reservoir quality. Marine and Petroleum Geology, 19, 873-900. 


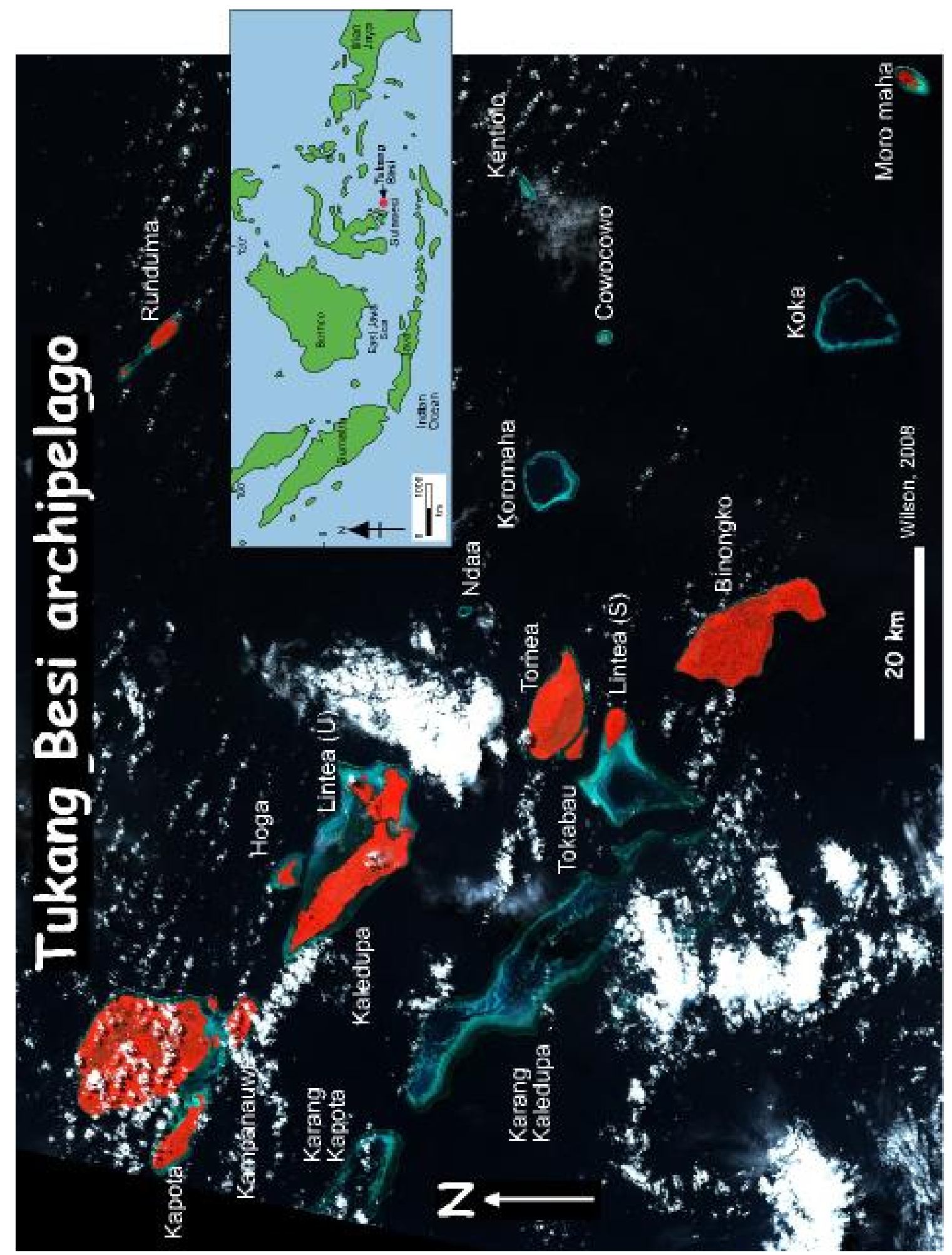

Figure 1) Satellite image of the Tukang Besi Archipelago (islands are shown as red). Inset map shows the location of the Tukang Besi Archipelago in Indonesia (Wilson, 2008). 


\section{Typical modern leeside profile, environments and sediment characteristics}
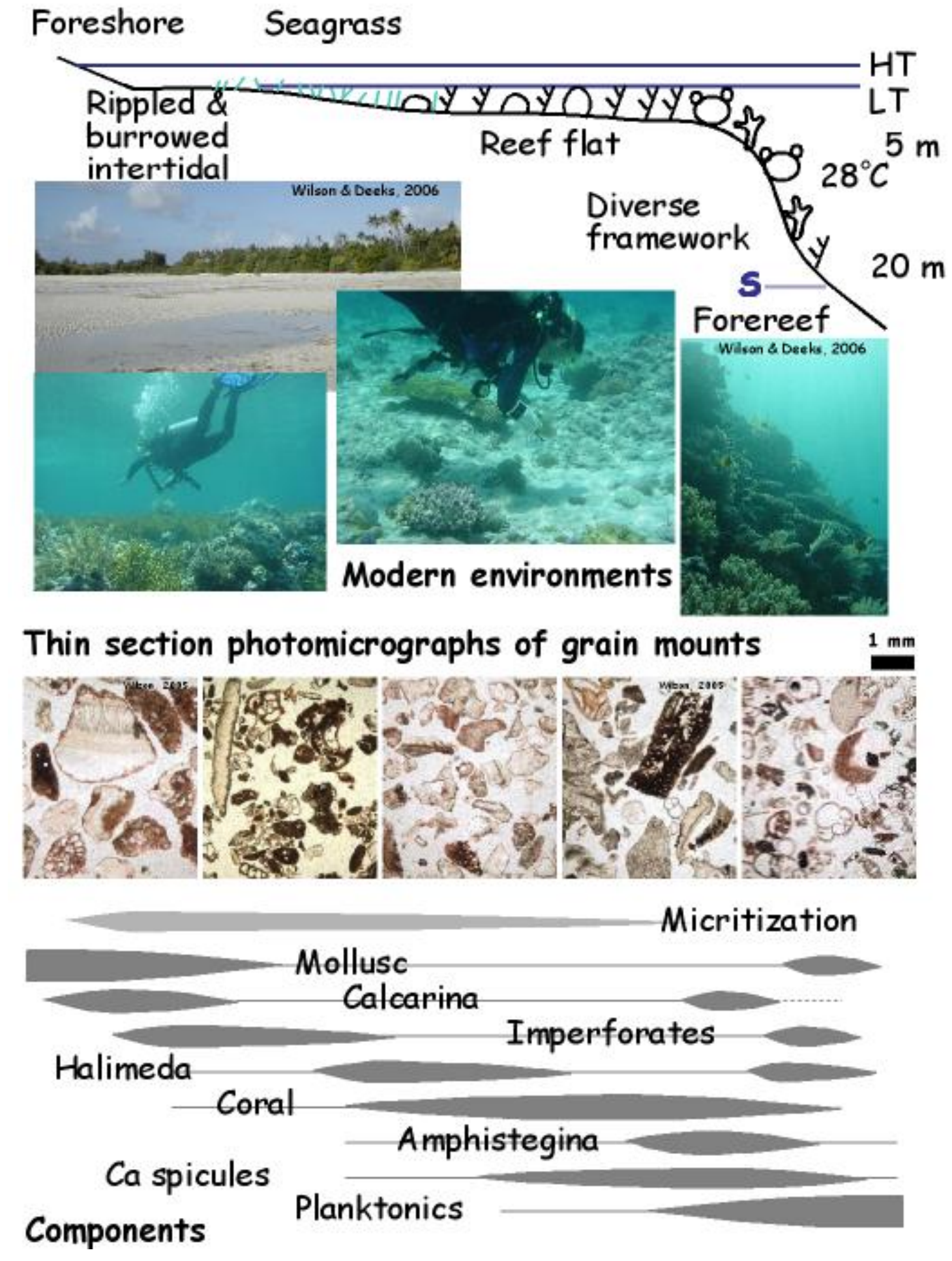

Figure 2) Typical leeside profile, modern environments and sediment characteristics from the Tukang Besi Archipelago (Indonesia; Wilson, 2008) 

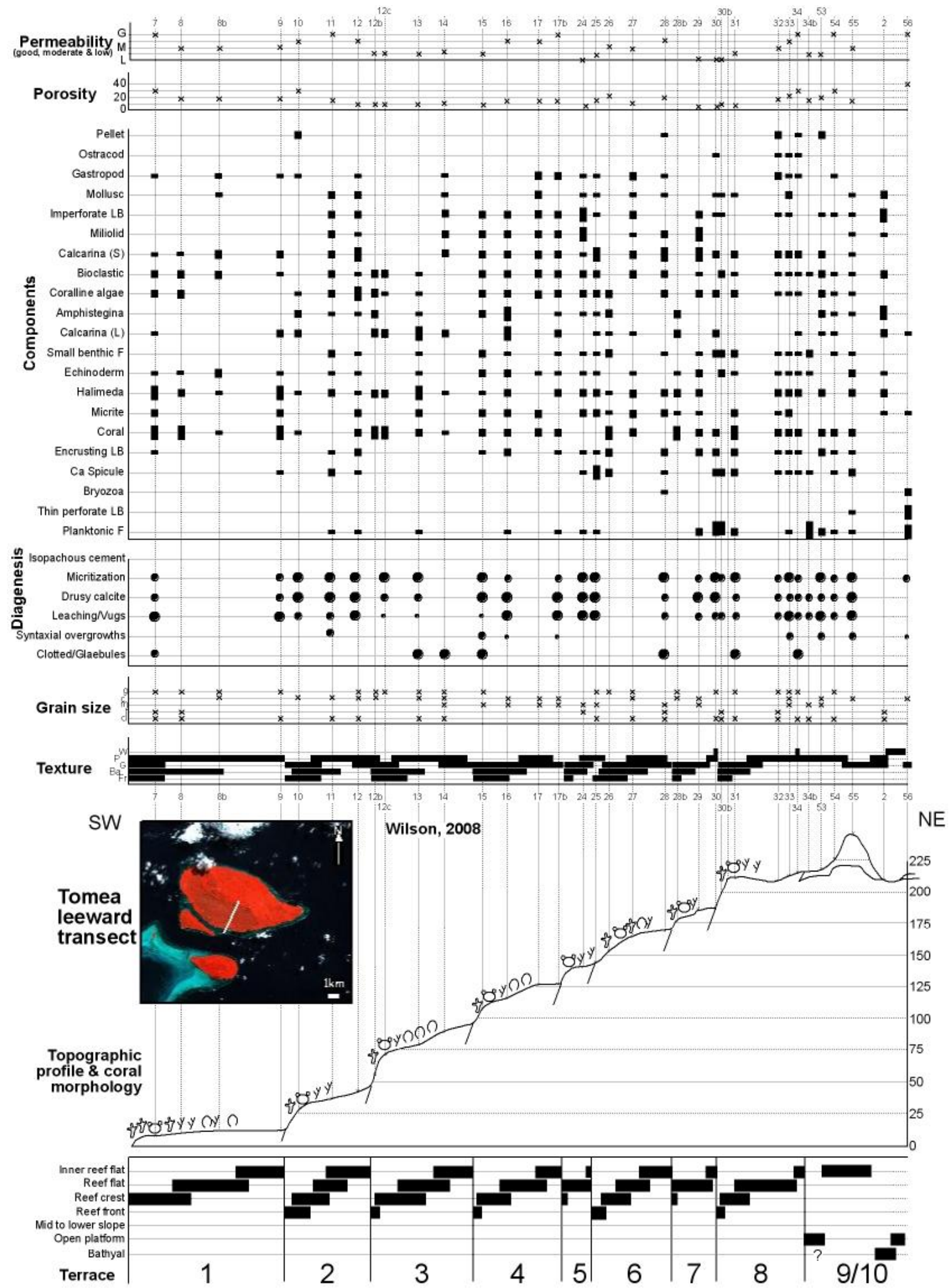

Figure 3) Example of one outcrop transect, and associated data collection, from the leeside of Tomea (inset satellite image shows location, Wilson, 2008). 